
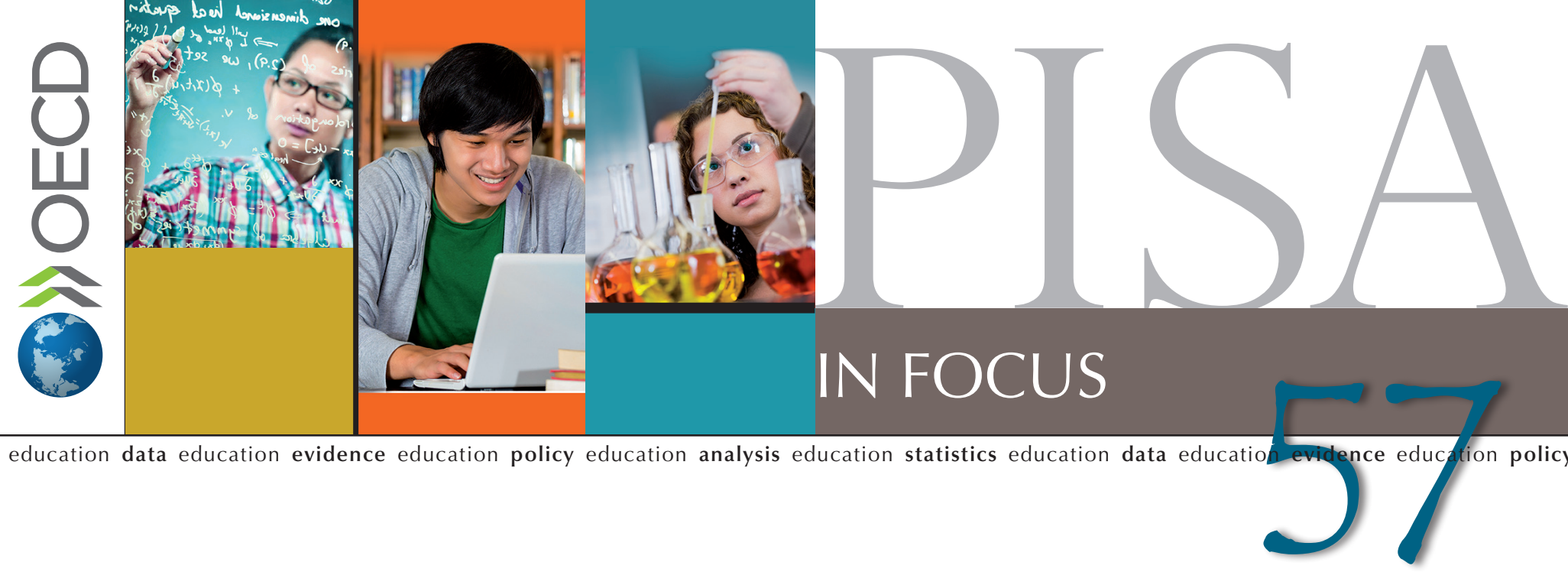

\title{
Can schools help to integrate immigrants?
}

- Only in some countries is a larger proportion of immigrant students in schools related to lower student performance - and this relationship is mostly explained by the concentration of disadvantaged students in these schools.

- Immigrant students from the same country of origin and similar socio-economic background often perform differently in different school systems.

- There is a strong connection between the performance of immigrants at school and their education and labour market outcomes as young adults.

Dramatic scenes of immigrants attempting to cross the Mediterranean in rough seas or scrambling over barbed wire fences have filled television and social media screens over the past few months. The debate on whether and how to accept these migrants has so far focused on border enforcement and admission policies. But this crisis should also be an opportunity to re-think integration policy, making sure that immigrants are given a fair chance to become productive citizens. PISA cannot yet provide information on students in the latest wave of immigrants; however, 2012 data yield important lessons on what schools can do to help young immigrants integrate into their new communities.

There has been an increase in foreign-born students, but it has mainly been concentrated in a few countries.

Evidence from PISA helps to distinguish the myths from the facts about how immigrant students perform at school and affect education systems. The first myth is that immigration to OECD countries has exploded over the past decades. The data show a more nuanced picture. First, the growth in the number of foreign-born students has been concentrated in a limited number of countries. The share of 15 -year-old students who are first-generation immigrants (foreign-born students whose parents are also foreign-born) grew by 0.4 percentage point, on average across OECD countries, between 2003 and 2012. This share grew by around 6 percentage points in Ireland, 5.5 percentage points in Spain, and 4 percentage points in Italy. Second, in other countries such as Canada, Luxembourg and the United States, changes in the profile of student populations were mostly the result of growing numbers of secondgeneration immigrants (students who were born in the country of assessment but whose parents are foreign-born).

Large proportions of immigrants in an education system do not necessarily affect student performance.

A second myth asserts that, above a certain threshold, a large proportion of immigrant students adversely affects an education system's performance. But data from PISA show that, across OECD countries, there is no significant association between the share of immigrant students and student performance. 


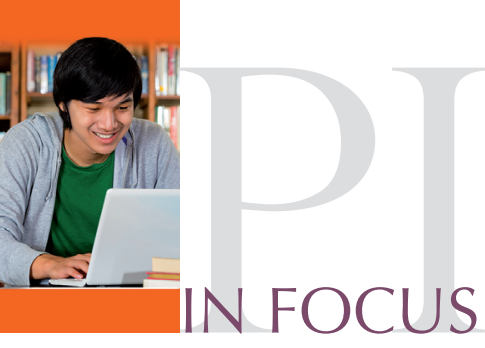

Change between 2003 and 2012 in the share of first-generation immigrant students Percentage of students

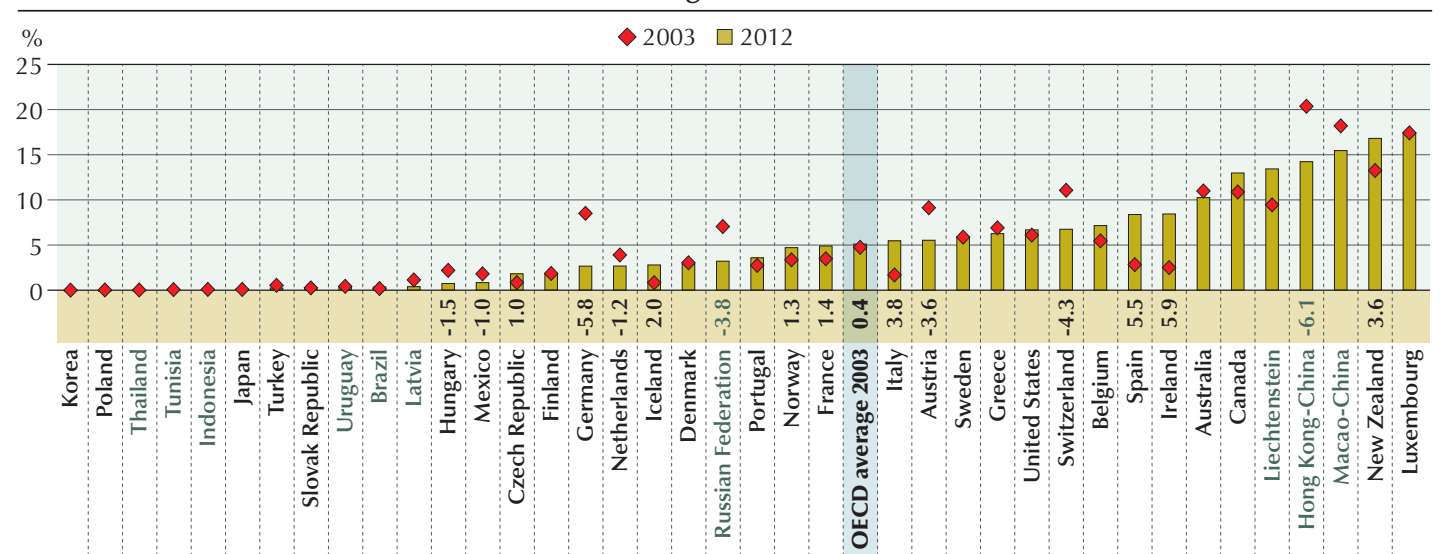

Notes: Only countries and economies with comparable data from PISA 2003 and PISA 2012 are shown.

The percentage-point difference between 2003 and 2012 in the share of first-generation immigrant students is shown above the country/economy name. Only statistically significant differences are shown.

OECD 2003 average compares only OECD countries with comparable data since PISA 2003.

Countries and economies are ranked in ascending order of the percentage of first-generation immigrant students in 2012

Source: OECD, PISA 2012 Database, Table II.3.4b

StatLink 解目 http://dx.doi.org/10.1787/888932964927

What is more strongly associated with performance than students' immigrant background is their socio-economic status, and that is most clearly observed within countries. Schools with larger concentrations of immigrant students are often located in poor neighbourhoods. In the United States, for example, $21 \%$ of all students have an immigrant background, but $40 \%$ of the students in disadvantaged schools do.

Concentration of disadvantage and its effects on student performance

Score-point difference in mathematics between schools with a high concentration of immigrant students and those without immigrant students

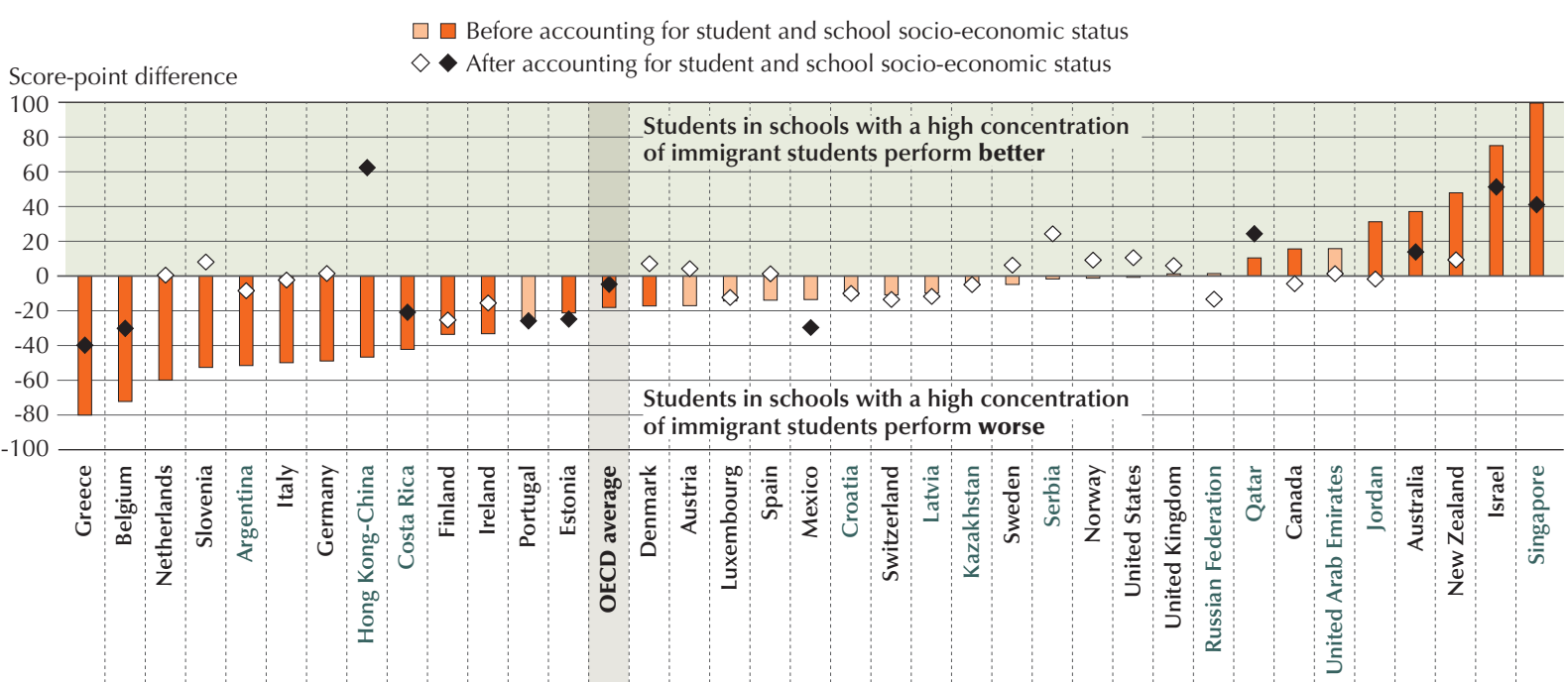

Notes: Statistically significant differences are marked in a darker tone.

Schools with a high concentration of immigrants are defined as those where more than a quarter of students are immigrants.

The model includes a variable indicating whether the student has an immigrant background.

Countries and economies are ranked in ascending order of the score-point difference in mathematics performance between schools with a high concentration of immigrant students and schools without immigrant students, before accounting for students' and schools' socio-economic status.

Source: OECD, PISA 2012 Database, Table II.3.9.

StatLink क्ता 


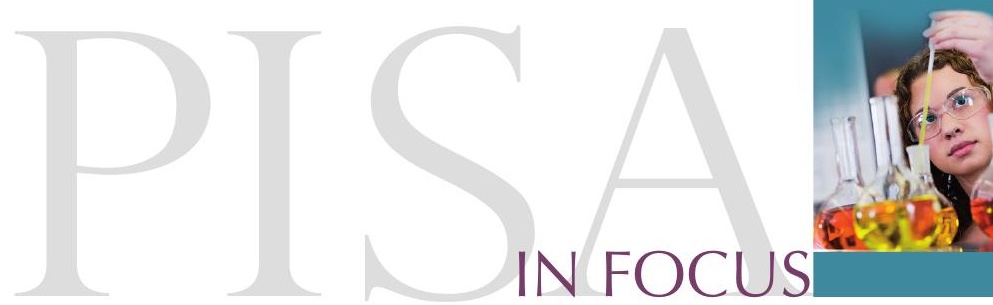

Across OECD countries, students who attend schools where more than 25\% of students are immigrants score 18 points lower in mathematics than those in schools with no immigrant students. The largest differences between the two types of schools are observed in Belgium, Greece and the Netherlands. After accounting for the socio-economic status of the students and schools, the average performance difference between schools with high concentrations of immigrant students and schools without immigrants is more than halved, to five score points, and loses statistical significance in most countries. PISA thus reveals that it is not the concentration of immigrant students in a school but, rather, the concentration of disadvantaged students in schools that hinders the achievement of both immigrants and non-immigrants.

\section{School systems in destination countries can influence the performance of immigrant students.}

School systems play an important role in the academic success of immigrant students, as seen in the fact that immigrant students from the same country and with similar socio-economic status perform differently in different destination countries. On average, foreign-born students from Arabic-speaking countries who live in the Netherlands score 100 points higher in mathematics than those who settled in Qatar, after accounting for socio-economic status. Albanian students in Greece score 50 points higher in mathematics than Albanian students with similar socio-economic status who settled in Montenegro - a difference that is very close to the average difference in performance between Greece and Montenegro. Students born in mainland China score above the OECD average in mathematics in several destination countries, but they tend to perform better in Hong Kong-China than in Macao-China. These patterns are also possibly explained by other background differences that influence both the choice of destination and the performance of immigrants.

Immigrant students' performance in mathematics, by country of origin and destination

$\square$ First-generation immigrants' score, after accounting for scoio-economic status $\square$ Second-generation immigrants' score, after accounting for scoio-economic status

\begin{tabular}{|c|c|c|c|}
\hline $\begin{array}{l}\text { Students from } \\
\text { Arabic-speaking } \\
\text { countries in: }\end{array}$ & $\begin{array}{r}\text { Netherlands } \\
\text { hited Arab Emirates } \\
\text { Denmark } \\
\text { Finland } \\
\text { Qatar }\end{array}$ & 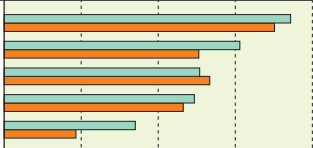 & \\
\hline Students from Iraq in: & $\begin{array}{r}\text { Netherlands } \\
\text { Finland } \\
\text { Denmark }\end{array}$ & \begin{tabular}{|l|l|l}
$\vdots$ & $\vdots$ \\
& \\
\end{tabular} & \\
\hline Students from China in: & $\begin{array}{r}\text { Hong Kong-China } \\
\text { New Zealand } \\
\text { Macao-China } \\
\text { Australia }\end{array}$ & 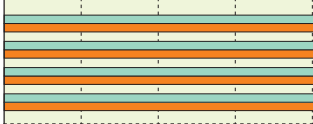 & בי \\
\hline Students from Albania in: & $\begin{array}{r}\text { Greece } \\
\text { Switzerland } \\
\text { Austria } \\
\text { Montenegro }\end{array}$ & 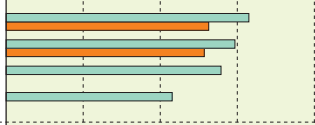 & \\
\hline $\begin{array}{l}\text { Students from } \\
\text { Bosnia and Herzegovina ir }\end{array}$ & $\begin{array}{r}\text { Germany } \\
\text { Croatia } \\
\text { Austria } \\
\text { Montenegro }\end{array}$ & 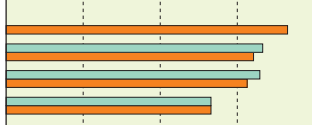 & \\
\hline $\begin{array}{l}\text { Students from } \\
\text { Russian Federation in: }\end{array}$ & $\begin{array}{r}\text { Finland } \\
\text { Latvia } \\
\text { Israel } \\
\text { Austria } \\
\text { Czech Republic } \\
\text { Kyrgyzstan }\end{array}$ & \begin{tabular}{|l|l|l} 
& \\
& \\
& \\
& \\
& \\
& \\
\end{tabular} & \\
\hline
\end{tabular}

Notes: The estimates are obtained by pooled data from the PISA 2003, PISA 2006, PISA 2009 and PISA 2012 Databases.

The average performance by immigrant group and destination country accounts for differences in socio-economic status. It corresponds to the predicted performance of the group if all the immigrant students who migrated from that country of origin and all non-immigrant students across all the destination countries shared the same socio-economic status of the average student. Only destination countries with data on at least 20 immigrant students are shown. Sources: OECD, PISA 2003, 2006, 2009, 2012 Databases.
Changes in the performance of immigrant students over time also suggest that education policies complement social policies in fostering integration. In less than one decade, for example, Germany managed to reduce the share of underperforming immigrant students by 11 percentage points and improve the mathematics performance of second-generation immigrant students by 46 score points the equivalent of more than one year of formal schooling (see PISA in Focus 53).

\section{Integrating young immigrants at school} yields long-term benefits.

Education systems need to anticipate the challenges inherent in diverse student populations. Delaying support to immigrant students can be costly, since the skills acquired at school determine, to a great extent, employability and social participation later on.

PISA does not follow the same students over time, nor does it compare education outcomes across generations. But the data show a strong relationship between the performance of first- and secondgeneration immigrants in most countries. 
